María Vázquez-Amador*

Universidad de Cádiz, Spain

maria.vazquez@uca.es

M. Carmen Lario-de-0ñate

Universidad de Cádiz, Spain

carmen.lario@uca.es

\title{
THE ROLE OF WOMEN IN BUSINESS ENGLISH TEXTBOOKS (1970s-2010s)
}

\section{Abstract}

Business English textbooks help students learn not only the language used in the world of business but also about the organizational structure of different companies as well as interaction in the workplace. This research examines the evolution of the professional role of women in Business English textbooks in the last fifty years. For this purpose, we analyzed thirty-five Business English textbooks published between the 1970s and the 2010s. Firstly, we recorded the different jobs done by women included in these books and classified them in four different occupational groups: managers, professionals, technicians, and clerks. As expected, the number of jobs held by women in these textbooks gradually increased over time although there has been likewise a remarkable decrease in clerical jobs as managerial and professional jobs experienced a simultaneous increase; the incidence of female technicians was consistently low. Regarding female representation in textbook pictures, whereas in the 1970s women were depicted in traditional female roles, we can observe how they are progressively portrayed in managerial positions. Furthermore, their visibility in general increased noticeably over the years. On the other hand, the representation of actual businesswomen in textbooks as case studies or part of reading comprehension exercises is quite limited.

\section{Key words}

Business English, textbooks, women, representation, female professions, professional categories.

\footnotetext{
* Corresponding address: María Vázquez-Amador, Departamento de Filología Francesa e Inglesa, Facultad de Filosofía y Letras, Cádiz, España/Spain.
} 


\section{INTRODUCTION}

English is currently the main language of communication in most social, cultural, and professional areas and this is particularly the case in business. Business English is a branch of English for Specific Purposes (ESP) which deals mainly with adult learners working or getting ready to work in a business context (Dudley-Evans \& St John, 1996). It focuses on the language skills essential to communicate effectively in a global business environment, incorporating a wide range of subjects necessary for the development of specialists trained to meet the needs of a growing economy (Bargiela-Chiappini \& Zhang, 2013). "Business English is an umbrella term for a mixture of general everyday English, general business English, and ESP. It is not limited to words or phrases that only appear in some special business world" (Frendo, 2005: 7). The language used in the workplace is not only about work but also about individual social experiences of life (McGroarty, 2002).

Business English began as a materials-led movement that produced many successful textbooks and teaching resources for business communication (St John, 1996). The publication of Business English materials dates back to the 1970s, and the number of textbooks increased dramatically in the 1980s and 1990s (DudleyEvans \& St John, 1996). "Of 24 ESP books claimed as new in 1994, 21 were businessrelated" (St John, 1996: 9). Before the 1980s, these books featured long texts for comprehension, focused on vocabulary, and emphasized commercial correspondence During the 1980s, however, the different units in these textbooks started off with a new section, an introduction or warm-up whose purpose was to encourage students to discuss a topic and learn new related terms (Lario-de-Oñate, 2007). Functions were a crucial element in Business English textbooks: "Business English teaching became thus more focused on functional areas - language for recommending, expressing opinions, giving advice, showing agreement, etc." (Zagan-Zelter \& ZaganZelter, 2010: 248). The teaching and learning of Business English had its peak in the 1990 s as a consequence of a shift from using English only for specific "international" operations to using English for organization-wide communication (Kankaanrant \& Louhiala-Salminen, 2013). In this decade, role-plays, simulations, and case studies were added (Lario-de-Oñate, 2007). After the turn of the millennium, new tasks and exercises focused on the intercultural component were introduced (Lario-de-Oñate \& Vázquez-Amador, 2013).

Business English textbooks enable students to learn not only the language used in business but also about the organizational structure of companies and their different departments as well as the roles played by employees and their interaction. Thus, Dzięcioł-Pędich (2017: 141) points out that “[c]ontemporary Business English coursebooks claim to bring the real world of international business into language classrooms". For decades, the content included in textbooks has been changing and evolving and "[t] extbook portrayals have altered over time to reflect societal views" (Clark, 2005: 241). 
This study explores women's professional roles in Business English textbooks from the 1970s to the 2010s, but does not compare either the number or type of jobs held by males or females. Since the last century, women have been fighting for equality both in the workplace and society as a whole, eventually bringing on a real social change. It is therefore of interest to evaluate how these changes are reflected in Business English textbooks. While there has been no close examination of this matter so far, this study aims to determine whether women's professional progress in society matches the information presented in these books.

\section{BACKGROUND}

Female labour force participation rate has increased sharply since the 1960s due to a number of factors such as the introduction of the birth control pill, the women's liberation movement, and other social movements (Jalilvad, 2000). In the 1970s, the number of working women increased to nearly $40 \%$. Nonetheless, it seems that they still contemplated employment as secondary to their domestic responsibilities (Domenico \& Jones, 2006). However, the number of women in the labour market has started to grow significantly and consistently from the early 1980s. In fact, women have exceeded men in pursuing higher education and moved forward to previously male-dominated employment sectors (Scott, Dex, \& Joshi, 2008). Yet, different barriers hold women back from finding a job (Molina-Plaza \& Allani, 2020). Barriers such as gender stereotypes, work-life balance and certain lack of required experience, among others, helped to create a "glass ceiling" which has hindered women's access to managerial posts (López-Fernández, Martín-Alcázar, \& RomeroFernández, 2009). This term was coined in 1978 and became popular in an article published in the Wall Street Journal in 1986 on women executives (Rincón, González, \& Barrero, 2017). In today's modern world, women still participate in labour markets on an unequal basis with their male colleagues (Dzięcioł-Pędich, 2017). In 2019 , the female labour force participation rate stood at $47 \%$, well below that of men (74\%) (World Employment and Social Outlook, 2020). Nevertheless, "by the end of the twentieth century, women were largely expected to work" (Walsh \& Wrigley, 2001: 1).

Over the past decades, many researchers have explored the role of women in textbooks of English as a Second Language (ESL) and English as a Foreign Language (EFL) focusing on a range of different issues and educational settings. Most of these studies have been undertaken in Asian and Middle Eastern countries. Thus, Giaschi (2000) analyzed the images in seven ESL textbooks and concluded that men always had active roles. More recently, Ziad and Ouahmiche (2019) examined the illustrations of three Algerian secondary education English textbooks and stated that most of them showed clear signs of bias against females. Ansary and Babaii (2003) studied sexist attitudes and values in two ESL textbooks for Iranian students at secondary schools and concluded that women were less visible than men. Bahman 
and Rahimi (2010) examined three English textbooks taught in Iranian high schools and the results revealed that sexism was manifest. Gharbavi and Mousavi (2012) carried out research on four English textbooks taught in Iranian high schools and found a significant difference between the frequency of male and female appearance in illustrations, texts, and occupational roles. Likewise, Roohani and Zarei (2013) studied potential areas of gender-bias in the representation of women and men in the pre-university English textbook used in high schools in Iran. They stated that, even though the presence of male-oriented features such as names, nouns, and pictures was remarkable, the textbook included many gender-neutral nouns and pronouns.

Along the same lines, Marefat and Marzban (2014) studied how visual and verbal discourses interact to represent gender identity in a national ESL textbook dialogue in Iran and concluded that females were invisible and underrepresented. On the other hand, Lee (2014) compared the status of women in Hong Kong in twelve English language textbooks for primary school published in 2005 and 1988. This study revealed that some stereotypes still prevailed despite an improvement in gender equity in more recent books. Healy (2009) detected some differences in women's and men's speech in a series of EFL textbooks for adult and young adult learners. Hamdan (2010) focused on a series of English language textbooks used in Jordan and found that men occupied most jobs (79\%). Amini and Birjandi (2012) analyzed three textbooks and concluded that sexism was present in this type of Iranian material. Amerian and Esmaili (2015) explored the representation of gender in EFL textbooks and found certain degree of sexist attitudes. Nashriyah and Khairul (2018) investigated whether women and men were presented equally in English textbooks in Indonesia and the results showed that women were more visible than men, who nevertheless were dominant in terms of quantity, firstness, and masculine generic construction.

Research into English textbooks used in other countries has also been conducted. Lee and Collins (2009) used content analysis to compare gender representation in ten English language textbooks for intermediate learners in Australia. They concluded that a balanced treatment of men and women had not been achieved yet. Holmqvist and Gjörup (2007) examined the occupations held by women or men in English textbooks in Sweden as well as the number of male and female authors and the distribution of male and female figures in their illustrations. They concluded that there is a tendency to promote men and diminish women in all textbooks. Filak (2002) analyzed EFL course books available to Polish learners between 1946 and 2001 to identify gender stereotypes and any related changes over fifty years. The results of the study showed that women had subordinate roles in most of the course books.

In addition, some researchers have analyzed textbooks of English for Specific Purposes (ESP). Adel and Enayat (2016), for example, examined the positioning of gender in the images and texts in ESP textbooks for Commerce, Nursing, Technology, and Tourism. The results indicated that most pictures show men as the active 
participants in the different contexts while women appear as far more reactive. In English for Commerce, men were particularly presented as the dominant group and women as subordinates.

Fuertes-Olivera (2007) studied lexical expressions of gender in specialized communication in a corpus of written Business English. The findings revealed that men were much more visible than women. Pillay (2017) found that men were depicted in high-status occupations with leadership positions in four Business Studies textbooks selected from countries in the Southern African Development Community (SADC). Likewise, Bataineh (2017) examined gender representation in the textbook Pre-Intermediate Market Leader: Business English Practice File (2012). The results showed that females were more visible than males in occupational roles, equally represented in terms of visibility, and less visible when dealing with firstness. On the other hand, Dzięcioł-Pędich (2017) reviewed the speaking sections of six Business English textbooks published between 2005 and 2014, and concluded that women and men had not only similar roles but also occupied equally high corporate positions. Finally, Goyal and Rose (2020) analyzed the first and latest editions of the Market Leader Course Book: Intermediate Business English for equality of gender representation and found that the latest editions show decreased male dominance in many images as well as in some speech elements.

Most of these studies aimed to determine gender representation based on male-to-female ratios, titles for addressing, firstness, illustrations and texts as well as occupational roles. They all adopted a synchronic approach and focused on the textbooks currently used in their countries. The studies comparing old and new textbooks for evidence of change are scarce (Goyal \& Rose, 2020), therefore we decided to examine the evolution of professional female roles in Business English textbooks over the last fifty years. We believe working across a relatively long span of time will help us to observe their progression. Moreover, most of the works aforementioned concentrate on one specific textbook or series of textbooks. However, we included a much larger amount of textbooks in our research - thirtyfive in total - so that we could gain a broader perspective of the situation of women.

\section{METHODOLOGY}

This diachronic study uses both qualitative and quantitative approaches: a systematic quantitative analysis of the female characters and a qualitative analysis of women in illustrations as well as the inclusion of actual businesswomen in texts. The sample includes thirty-five textbooks which are easily available at the University of Cádiz library and have been used to teach Business English to university students in the last fifty years: four were published in the 1970s, eight in the 1980s, 1990s and 2000s, and seven in the 2010s. The aim was to show a fair representation of the five decades under study. The texts were chosen from various publishing houses (all of them were British except three - two American books and 
a Spanish one), and all were intermediate level (lower intermediate, preintermediate, intermediate, and upper-intermediate) except for two at elementary level and two for beginners.

Systematic recording and tabulation of the female jobs were carried out for each of the thirty-five textbooks. These data were treated statistically to analyze trends. In addition to these frequency counts, the study examined illustrations and the inclusion of successful businesswomen as well. Once recorded, the occupations were classified according to the International Standard Classification of Occupations 2008 (ISCO-08) (ISCO, 2016) - a tool for organizing occupations into clearly defined groups according to their respective tasks and duties. The aims of this classification, developed by the International Labour Organization (ILO), are to promote rights at work and decent work for women and men.

Even though ISC0-08 establishes ten major groups based on their similarity in terms of skill level and skill specialization, in this research we considered the first four groups only, business-related and summarized in Table 1. Non-businessrelated professions were excluded (e.g. conference attendants, career coaches, students, trainees, interns, maids and university professors).

\begin{tabular}{|l|l|l|}
\hline JOB GROUP & DUTIES & EXAMPLES \\
\hline Managers & $\begin{array}{l}\text { Plan, direct, coordinate, and evaluate } \\
\text { enterprises' overall activities. }\end{array}$ & $\begin{array}{l}\text { Top, senior and middle } \\
\text { management positions: CEO, } \\
\text { managing director, manager, } \\
\text { entrepreneur. }\end{array}$ \\
\hline Professionals & $\begin{array}{l}\text { Conduct analysis and research, advise } \\
\text { on or apply existing knowledge related } \\
\text { to technology, social sciences, or } \\
\text { provide legal and social services. }\end{array}$ & $\begin{array}{l}\text { Accountant, analyst, auditor, agent, } \\
\text { consultant, lawyer, exporter, } \\
\text { manufacturer. }\end{array}$ \\
\hline Technicians & $\begin{array}{l}\text { Support managers and professionals } \\
\text { performing technical services and } \\
\text { apply concepts and operational } \\
\text { methods to different fields. }\end{array}$ & $\begin{array}{l}\text { Customer sales assistants, research } \\
\text { assistants. }\end{array}$ \\
\hline Clerical Support Workers & $\begin{array}{l}\text { Perform general office tasks such as } \\
\text { filing, record keeping, typing, mailing, } \\
\text { phone answering, data entering, and } \\
\text { similar tasks. }\end{array}$ & $\begin{array}{l}\text { Clerk, typist, receptionist, } \\
\text { switchboard operator. }\end{array}$ \\
\hline
\end{tabular}

Table 1. International Standard Classification of Occupations 2008

Illustrations were also examined in this study as a crucial component of textbooks since they not only support texts but also convey meaning on their own. Visual elements were observed to illustrate the evolution in the perception of professional women in the last fifty years as pictures and other kind of visual elements progressively became an important part of instruction (Arikan, 2005). The women depicted in illustrations, cartoons, drawings or photographs were recorded and the different tasks they performed in them were noted down to obtain further information about cultural and social issues. These images were evaluated according to the female character's activity depicted only. Body language, women's 
position related to men or any other related factors were not analyzed. One example of this is the classic depiction of women in the 1970s performing clerical work or even non-business-related jobs such as cashiers in supermarkets. However, from the new millennium, it became very common to represent women giving presentations or leading meetings. Some textbooks included texts about actual successful businesswomen; their names and professional positions were compiled, as well as the type of business they owned or worked for.

Finally, the information gathered was organized by decades to interpret the findings and look at how female characters were presented in textbooks and the way their roles have evolved over the last fifty years. Women's activities in pictures and the actual businesswomen included in the texts were used to support conclusions from the quantitative approach.

\section{THE STUDY}

The thirty-five textbooks reflect the wide variety of occupations related to the business world. Almost two hundred different jobs were found, although many were not business-related proper (a TV presenter, a TV producer, a university professor, conference attendants, students, etc.); therefore the actual number used was 174 . All of these occupations were grouped in the four aforementioned ISCO categories: managers, professionals, technicians, and clerks (clerical support workers).

\subsection{The 1970s}

The four books published in the 1970s are for intermediate learners. In general terms, male characters have the leading roles whereas females are almost invisible. In two of these books, Business World (Barber, 1974) and The Language of International Trade in English (Mohr, 1978), women are only present in illustrations and they usually perform non-business-related jobs (a cashier in a supermarket, a teacher, a waitress). English Commercial Practice and Correspondence (Eckersley \& Kaufmann, 1973) includes four women in clerical positions (filing clerk, secretary, switchboard operator, and typist). The Language of Business (Mack, 1972), however, depicts two women in the professional group (both representatives of shop floor workers and clerical staff) and two female managers (an account manager and an advertising manager).

In total, there are only twelve women represented in these books. Eight of them performed administrative jobs (clerks according to ISC0-08 classification): filing clerk (1), secretary (5), switchboard operator (1), and typist (1); two were representatives (professionals according to ISC0-08), and only two were managers (an account executive and an advertising manager). It is also worth mentioning the differences among the books. There are non-business-related jobs in two textbooks 
and only clerical jobs (4) in another. However, the number and variety of jobs are greater in the fourth textbook (four clerical, two representatives and two managers). Although women still occupied low responsibility positions, they were timidly starting to be part of the business world.

Regarding the use of pictures and illustrations, it was clearly not a common trend in those years. However, among the textbooks reviewed, Business World (Barber, 1974) includes a significant number of them, as stated in the Introduction: "There are ample photographs, sketches and questions within the text providing a simple informative and interesting introduction to the traditional approach to the study of Commerce" (Barber, 1974: 6). Most of the pictures show female secretaries or women doing the shopping or else working as cashiers in supermarkets. In Illustration 1, from English Commercial Practice and Correspondence (Eckersley \& Kaufmann, 1973: 86), a cartoon represents an image in which the female character is clearly objectified (a man returning his wife because he is not satisfied with "his acquisition").

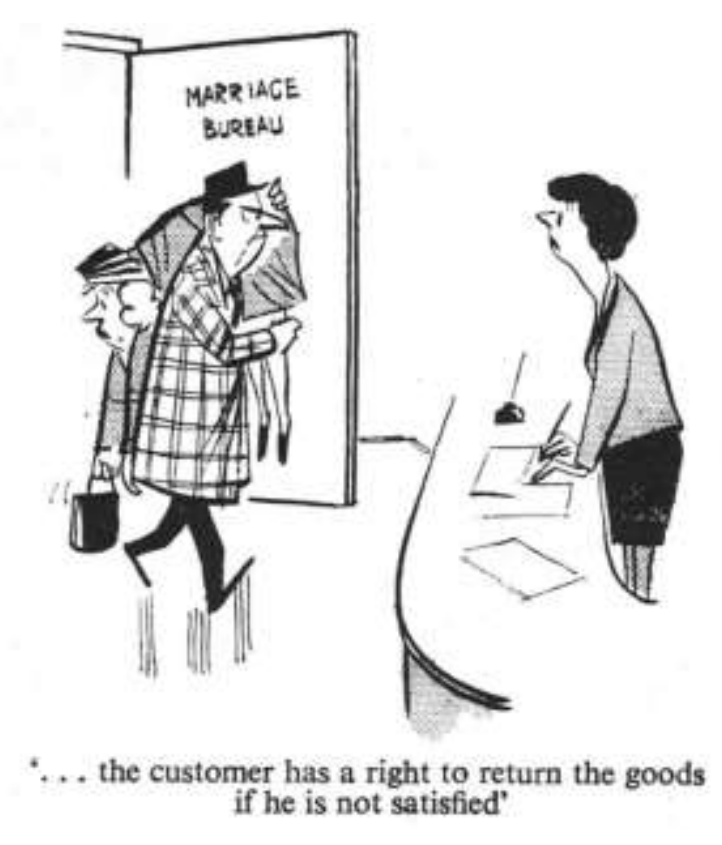

Illustration 1. English Commercial Practice and Correspondence, p. 86

\subsection{The 1980s}

Most of the eight books from the 1980s are for intermediate learners too, except for one elementary. These textbooks portray a more varied range of female occupations than those in the 1970s and there are many examples of women represented in leadership and management roles. As in the previous decade, the difference between books in terms of the number of jobs was quite noticeable. Six textbooks portrayed fewer than ten jobs and two of them - World of Business (Cotton, 1984) 
and Keys to Management (Cotton, 1988) - included 18 and 24 female characters respectively. At the end of the preface of Assignments in Business Studies (Danks \& Cross, 1989: 5), there is a footnote about the use of "he" and "she": "For reasons of textual fluency you will find the words 'he' or 'she' have sometimes been used in the book. However, in most cases, the person referred to could be of either sex". Nevertheless, feminine pronouns are barely used in the book and only two female characters are mentioned: a clerk and a shop owner.

In this decade, the number of women occupying managerial positions (58\%) is quite high compared to clerical jobs (25\%), professionals (11\%) and technicians (6\%). In Business in English (Hacikyan \& Gill, 1980), two women were promoted, one from Assistant Marketing Manager to Marketing Director, and the other one from Controller to Vice President of Finance. Most of the managerial jobs are shown in two of the textbooks, World of Business and Keys to Management, both by the same author, David Cotton. World of Business (1984) showed 17 jobs, and more importantly, a high percentage of managerial professions (12) followed by four clerical jobs, one professional and no technicians at all. In Keys to Management (1988), 24 female characters were recorded. The number of female managerial professions was relatively high (18), with a CEO, a Sales Manager, a Personnel Manager, a Finance Manager, a Production Manager or an Executive. Only two women performed clerical jobs and four had professional jobs as suppliers or representatives.

Most women in illustrations are depicted accomplishing office duties (e.g. typing, note writing or using the phone). World of Business (Cotton, 1984) does not have many pictures but in Unit 12 - "The EEC textile industry" - there is one showing a manufacturing plant with women machine sewing. The caption reads: "A housewives' factory in Tientsin, China, where machine-embroidered aprons, pillowslips, and tablecloths are produced" (Cotton, 1984: 97).

Concerning actual businesswomen, texts about them are included in World of Business (Cotton, 1984). In the Introduction, the author highlights that the texts are about recent trends, problems and successful organizations. There are two texts about two women, both in the fashion industry: Gloria Vanderbilt and Veronica Moss. The text about the former is included in Unit 2 with the title of "Gloria Vanderbilt jeans" as her blue jeans design was trendy in the late 1970s; the text is about how the image of jeans has changed, describing Ms. Vanderbilt as a promoter of the product with an image of health and elegance. Surprisingly, Veronica Moss in Unit 11 is just the name of a British wedding dresses firm expanding into other markets at the time.

\subsection{The 1990s}

Most of the books from the 1990s were also intermediate (two pre-intermediate, one lower intermediate, three intermediate, and one upper-intermediate) although 
there was one for elementary students. The number of female occupations mentioned or described in these textbooks is 83, quite similar to the previous decade, although 3 of the women were conference attendants, so the actual number is 80 . The most significant differences are in the clerk group, which decreased from 18 in the 1980s to eight in the 1990s. On the other hand, the number of professionals increased from eight to 25 and includes accountants, representatives, or suppliers. Despite differences in numbers among the textbooks, they are not as significant as in the previous decades. Business Class (Cotton \& Robins, 1993) is the textbook with the largest number of female characters, 15: 12 as managers and three as professionals. It is the first book in its area that introduces entrepreneurs, here categorized as managers. Business Basics (Grant \& McLarty, 1995) introduces 14 women: 3 clerks, 6 professionals and 5 managers, one of them being the founder of a company. Getting Ahead (Jones-Macziola \& White, 1993) includes 13 women working in business ( 5 professionals, 4 managers and 4 clerks). In Unit $14-$ "Entertaining" - an article by an American businesswoman titled "This working life", explains the difficulties women endure to perform the same tasks as their male colleagues in the world of business. She gives the example of dining out with a client or a business contact. "If people from the office see two men they know having dinner together, they think it's business. If colleagues see a woman dining with a man, they often wonder if it's another kind of business" (Jones-Macziola \& White, 1993: 79). Management-related jobs prevail in most of the textbooks, followed by professional ones, whereas technician professions are not so popular (4 in total). Clerical jobs are only mentioned in 3 of the books. The issue of women in business seems to have been a stimulating topic at that time. Business Class (Cotton \& Robins, 1993) includes a striking text titled "The spare sex, women in management" included in the Unit "Caution: People at work". It describes how difficult it is for women to be promoted in a company (climbing the ordinary corporate ladder) and explains why. A woman says: "Our managers are all white, middle-aged men, and they promote in their own image" (Cotton \& Robins, 1993: 99). Modern issues such as positive discrimination and mommy-tracks are also covered in the article.

Most pictures in the books analyzed for this decade represent women in meetings or giving presentations but also working as secretaries. Insights into Business (Lannon, Tullis, \& Trappe, 1993) does not include many pictures of women, although the few ones shown are mainly in meetings. In Unit 2 - "Recruitment" - the text "Looks: Appearance counts with many managers" points out the arbitrary rules used in recruitment departments and defines morphophysiology as an "attempt to determine personality traits according to a job applicant's face, eyes, mouth, nose, ears and hands" (Lannon et al., 1993: 16); the picture illustrating the text displays a pretty businesswoman. On the other hand, Getting Ahead (Jones-Macziola \& White, 1993) ventures to present gender-related, racial, and cultural diversity. There is a similar proportion of male and female characters featured in the book.

It is also worth mentioning that four women are introduced in texts about actual businesspeople. Insights into Business (Lannon et al., 1993) in Unit 7 - 
"Business and the environment" - depicts Anita Roddick, founder and managing director of the cosmetic company The Body Shop International, who started the company from a small shop in Brighton. Unit 11 - "Corporate alliances and acquisitions" - includes a text on the alliance formed by Renault and Volvo and a listening exercise in which Margareta Galfard, the director of Information and Public Relations Affairs for Volvo, explains some of the advantages of the alliance. In Getting Ahead (Jones-Macziola \& White, 1993), Unit 6 - "Day-to-day work" - Prue Leith, a chef with a Michelin-starred restaurant, describes an ordinary day in her life. Business Class (Cotton \& Robins, 1993) in Unit 13 - "The entrepreneur" - features Dounne Alexander, "a hard-working single mother" that puts her grandmother's recipes on the supermarket shelves. These examples of female entrepreneurship highlight the enormous economic and social transformations that have taken place in modern society and women's contribution to the creation of wealth and employment.

\subsection{The 2000s}

As in previous decades, most textbooks were intermediate level (4 intermediate and two upper-intermediate) except for two books for beginners. Ninety-four female characters were recorded in these textbooks all in all. Nevertheless, seven of those women have been excluded because their professions are not business-related (a TV presenter, a TV producer, a University professor, an artist, an MBA student, an engineering student, and a maid). Most women working in business have managerial positions (64\%), $20 \%$ are professionals, $11 \%$ are clerks and only $5 \%$ are technicians.

Market Leader (Cotton, Falvey, \& Kent, 2006) is the book that features not only the most female professions but also the highest number of female managers (18). Head for Business (Naunton, 2000) includes 15 female characters, 10 of them are managers, three are professionals, one is a technician and one is a clerk. Unit 5 "Fitting" - introduces a fascinating text about sexual discrimination: A company was sued (and found guilty) because they requested a female employee to change into a skirt or dress after coming to work in a trouser suit. Similarly, In Company (Powell, 2009) introduces 13 female professions ( 9 managers and four professionals). In this textbook, Unit 5, titled "What women want", is entirely about differences between male and female customers. Companies design and market products taking into account female purchasing power and their main role as decision-makers.

New International Business English (Jones \& Alexander, 2000) included ten jobs performed by women: six of them are management-related, three are professional and one is clerical. This book includes a very stimulating activity on page 50 in which students are asked to create two lists: one list should include jobs that women do nowadays but their mothers did not use to do in the past and a second list with jobs their mothers' generation used to do but women do not do 
today. The second part of the exercise is a discussion with questions about the past ("Why do you think the changes took place?") and also about the future ("What further changes do you expect and would you like to see?"). Curiously, Commerce (Hobbs \& Keddle, 2006) presents the highest number of women as clerks (two secretaries, one copywriter, and three switchboard operators). Although Start-up (Ibbotson \& Stephens, 2006) only portrays three female professions, women are present throughout the textbook in very active roles. Business Vision (Wallwork, 2002) uses the word "chairperson" instead of chairman or chairwoman as used in other textbooks.

Concerning pictures (see Illustration 2) New International Business English (Jones \& Alexander, 2000: 55) includes a sarcastic cartoon strip about what the world would be like "if women acted like men" titled "The world turned upside down". It shows the words used by women to address men such as "gorgeous", "dear", "good boy", "darling", "little gentleman", "angel" or "pet" as well as female and male attitudes: females as patronizing, even aggressive, and males as submissive creatures.

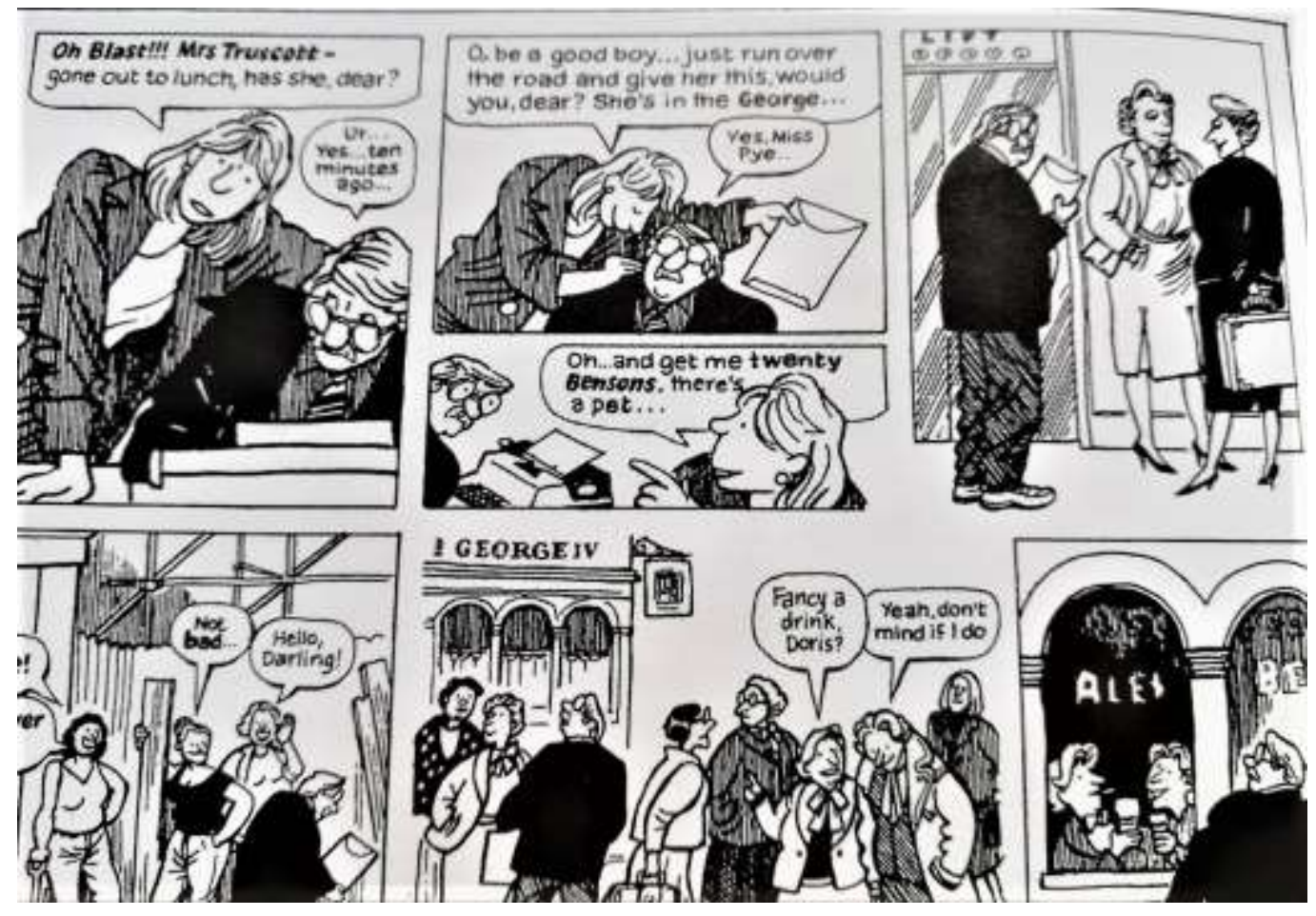

Illustration 2. New International Business English, p. 55

\subsection{The $2010 \mathrm{~s}$}

The seven books analyzed for this decade are for intermediate learners (6 intermediate and 1 pre-intermediate) although most textbooks published in this 
decade are edited using the Common European Framework of Reference for Languages rather than the levels referred to in this article. The total number of female business-related professions in these textbooks is 78 and trainees, fashion designers, career coaches, etc. were left out again. Women are consistently present in these books, although their occupations are very frequently not mentioned (e.g. "She works for a UK manufacturing company", Business Plus [Helliwell, 2014: 31]). As in former decades, the number of female managerial positions is higher than the rest of the categories. Fifty-five women performed management-related jobs, 17 were included in the professional category, 3 were technicians, and 3 had clerical occupations. The difference in job numbers between the books was quite evident. In Career Express (Maier-Fairclough \& Butzphal, 2013), 18 women worked in business; in Business Advantages (Birkin, 2012), 17 female jobs were mentioned and in The Business 2.0 (Allison \& Emmerson, 2018) there were 15. In those three textbooks, most women were in management positions, some were professionals and no clerical jobs. The pattern is similar in Business Partner (Dubicka et al., 2018) since 9 out of the 13 female professions are in management. In Business Result (Hughes \& Nauton, 2017), 5 women are managers and 2 are professionals. The presence of women in the remaining textbooks is not significant.

Women are represented in illustrations and are constantly present in pictures and photos in all kinds of business situations, which projects an inclusive image of women in the business world (see Illustration 3).

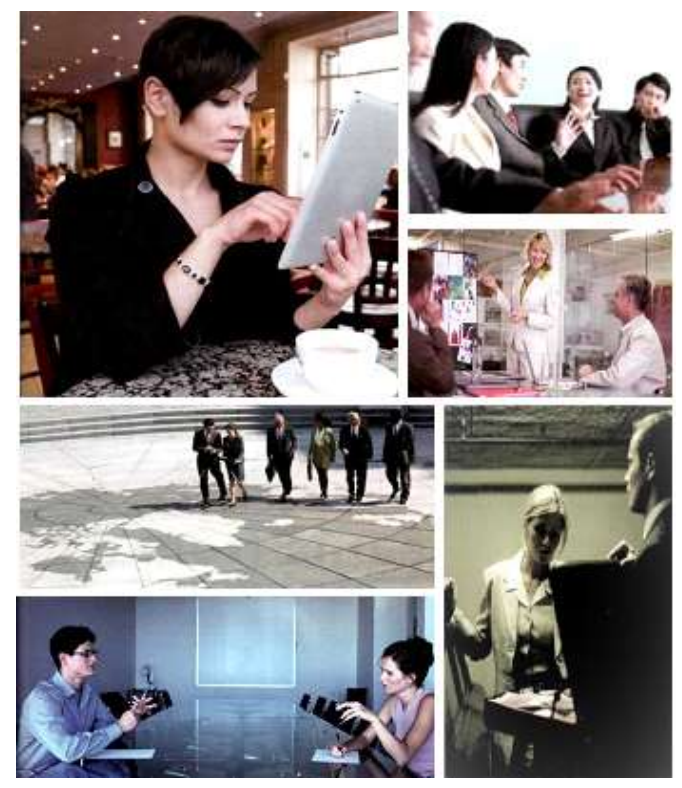

Illustration 3. Business 2.0., several pages

Business Advantage (Birkin, 2012) includes several actual businesswomen. Female managers are interviewed as part of the reading and listening exercises in the case studies. These women are: Pia Ørskov, Human Resources Manager of Creativ 
Company; Susan Heathfield, founder of Heathfield Consulting Associates; Dr. Ursula Knorr, head of University Institute for Leadership and Human Resource Management in Switzerland; Sharon Wright, founder of Talpa Products Ltd and Anuradha Desai, Executive Director of International Center for Conciliation. Likewise, Business Result (Hughes \& Naunton, 2017) includes Laure Pears who opened a cat café in East London by raising financial support through crowdfunding.

Even though we can see the number of different jobs represented in textbooks is much limited in this decade, women are more present than ever, and their status seems to have been completely normalized. Jobs are not male or female anymore, they are genderless. Women hold as many and relevant positions as men and no jobs in particular are mentioned any more, as the focus has been shifted to the company or the product itself.

\section{RESULTS AND DISCUSSION}

The analysis of the thirty-five textbooks generated 329 female characters in business. They ranged from jobs traditionally associated with women, such as secretaries, switchboard operators or receptionists, to top managers. It is significant how women have always been portrayed according to social and labour market changes. The number of female jobs in the textbooks increased over time (12 in the 1970s; 71 in the 1980s; 80 in the 1990s; 88 in the 2000s; and 78 in the 2010s).

Figure 1 shows there has been a fall in the number of professions in the 2010s, largely due to the lack of specification of female occupations - women are consistently present in the textbooks but their positions are not explicitly mentioned anymore.

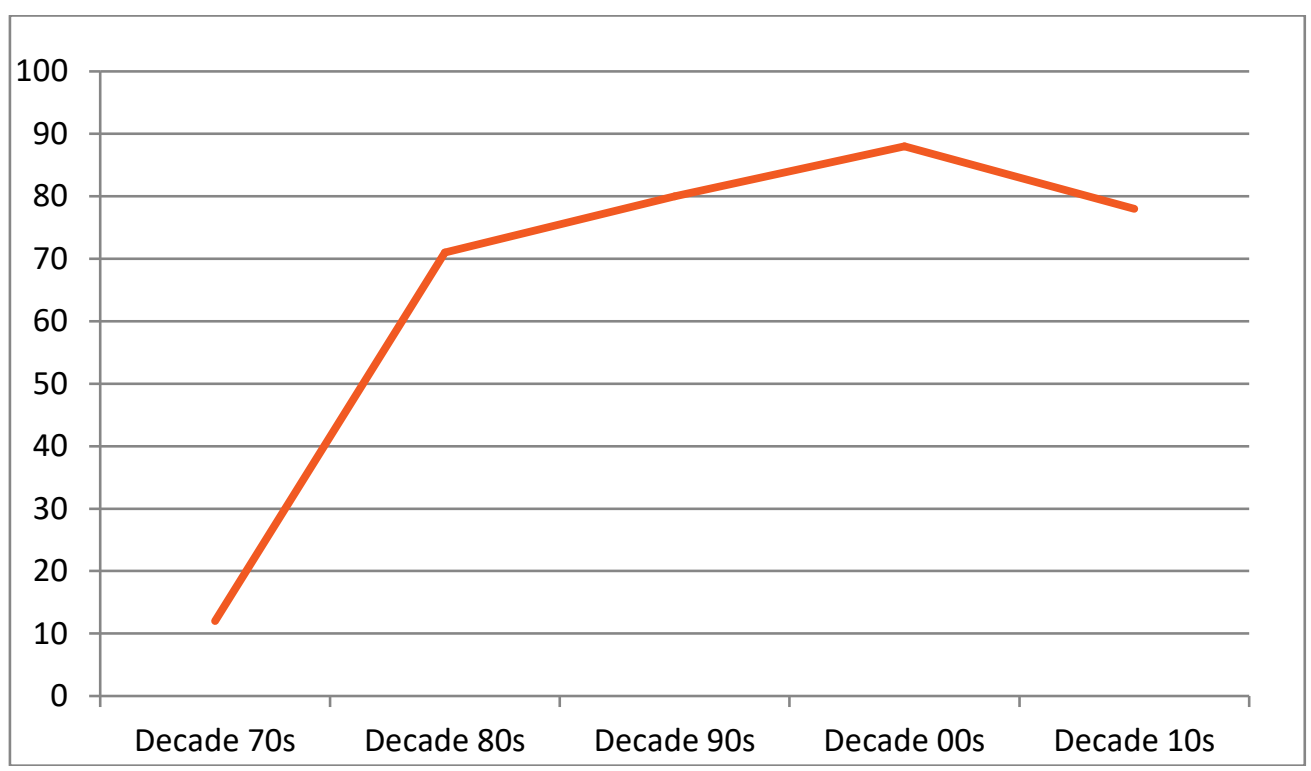

Figure 1. Number of professions in textbooks between the 1970s and the 2010s 
In terms of professional classification, the most relevant findings are a decrease in clerical jobs while managerial jobs experience a remarkable increase. On the other hand, female professional jobs show a similar incidence in each of the five decades, having their peak in the 1990s. Finally, female technicians are, in general, relatively uncommon in the textbooks used in this study. In the 1970s, most of the female characters recorded held clerical occupations (67\%); in those years these were the traditional jobs for a woman in business. The number decreased to $25 \%$ during the next decade, whereas the 1990s revealed just $10 \%$ of the female occupations in this category. A very similar percentage was recorded in the 2000s (11\%) and an even lower one in the 2010s (4\%) (see Figure 2).

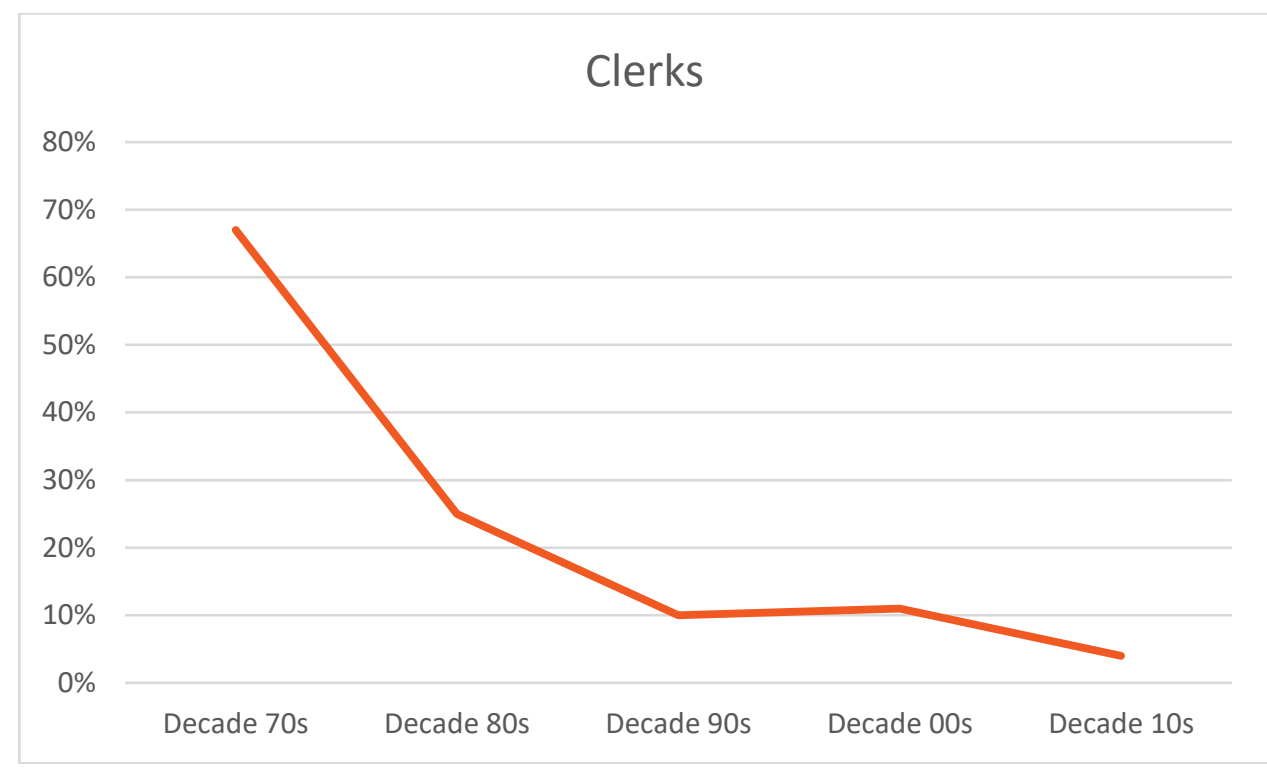

Figure 2. Clerks in textbooks between the 1970s and the 2010s

Interestingly, female technicians were barely included in the textbooks, and no relevant differences between the different decades were perceived. Their presence was $0 \%$ in the 1970 s, then increased to its highest (6\%) in the 1980 s and finally dropped to $4 \%$ in the 2010 s. Most of the jobs in this category were assistant position (research assistant, sales assistant, customer sales assistant, etc.).

On the other hand, as shown in Figure 3, the number of professional women was relatively high in general and on the increase over the decades. In the 1970s, there were only two female professionals. This figure was higher in the 1980s, with eight female professionals (11\%) and peaked in the 1990s at 31\% (25). However, this category fell to $20 \%$ (18) in the 2000s and stood at $22 \%$ (17) in the 2010 s. The main occupations recorded in this group were accountant, auditor, consultant, controller, exporter, representative, and supplier. 


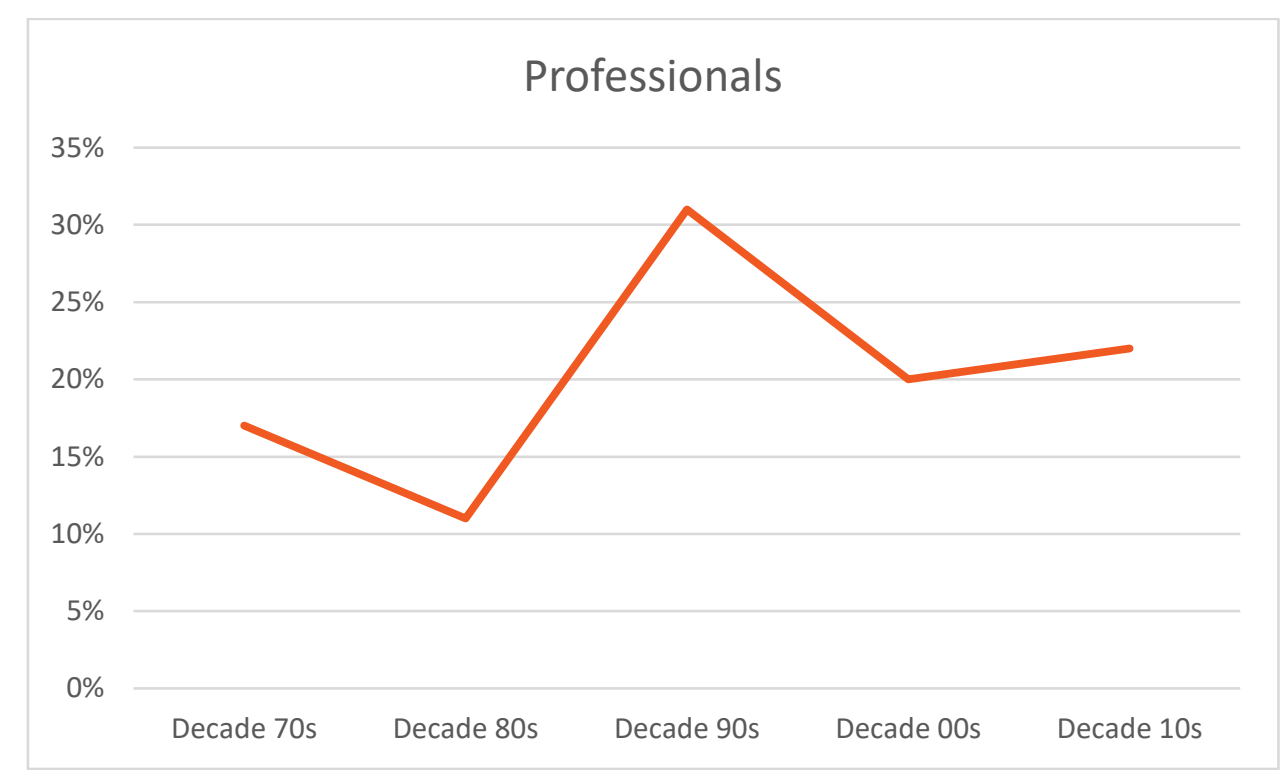

Figure 3. Professionals in textbooks between the 1970s and the 2010s

Managerial professions showed a swift progression as only two female managers were reported in the 1970s. This number increased to $41(58 \%)$ in the 1980 s and $43(54 \%)$ in the 1990s. It was even higher in the 2000s, with $56(64 \%)$ and $55(71 \%)$ in the 2010s.

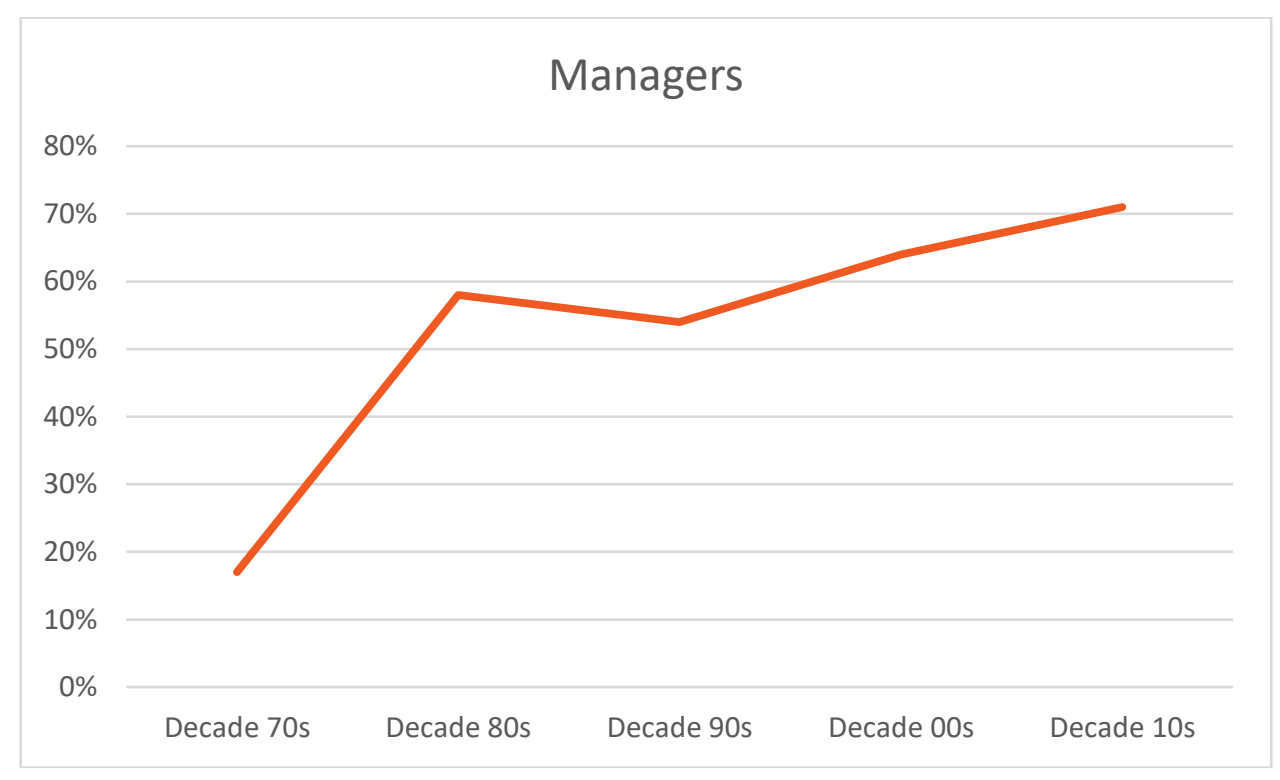

Figure 4. Managers in textbooks between the 1970s and the 2010s 
Figure 5 shows how the trend has progressively reversed over the years. The most common category in the 1970 s was clerks whereas in the 2010 s it is managers.

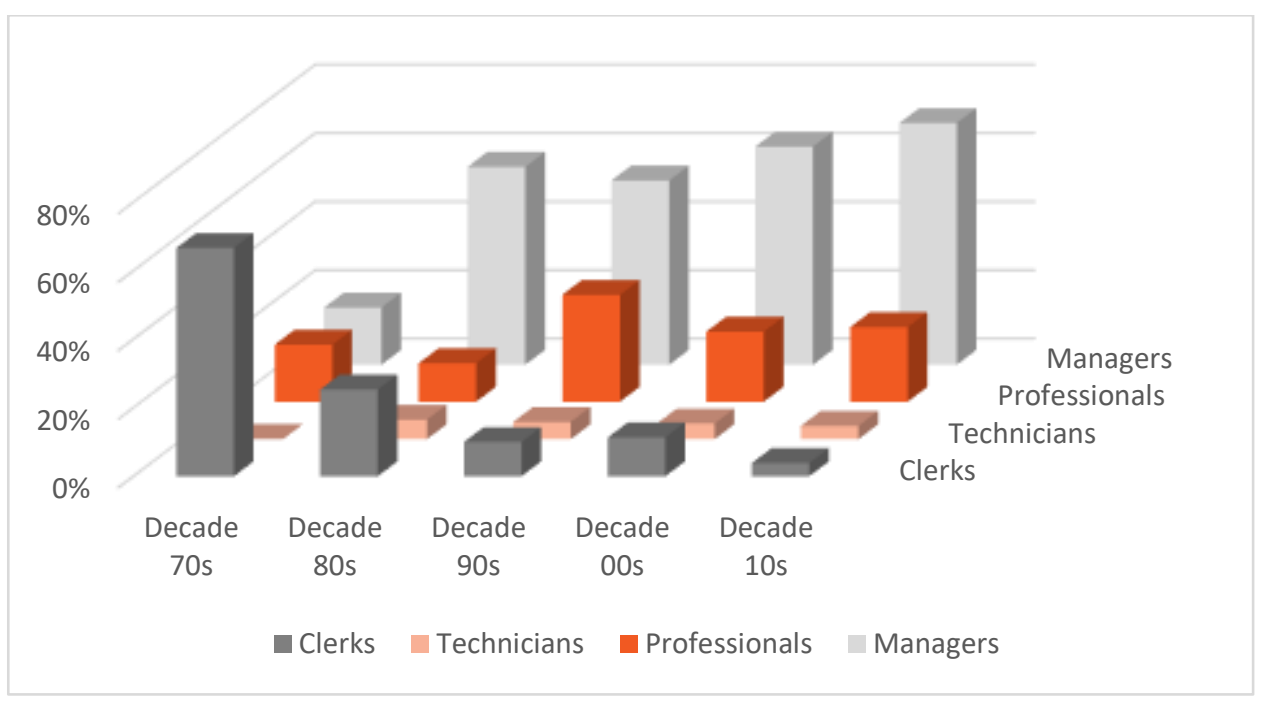

Figure 5. Categories in textbooks between the 1970s and the 2010s

As it is evident from Figure 1, the number of working women has experienced a radical growth, most female characters in this study are in managerial positions due to an improvement in their business roles, as shown in Figure 6.

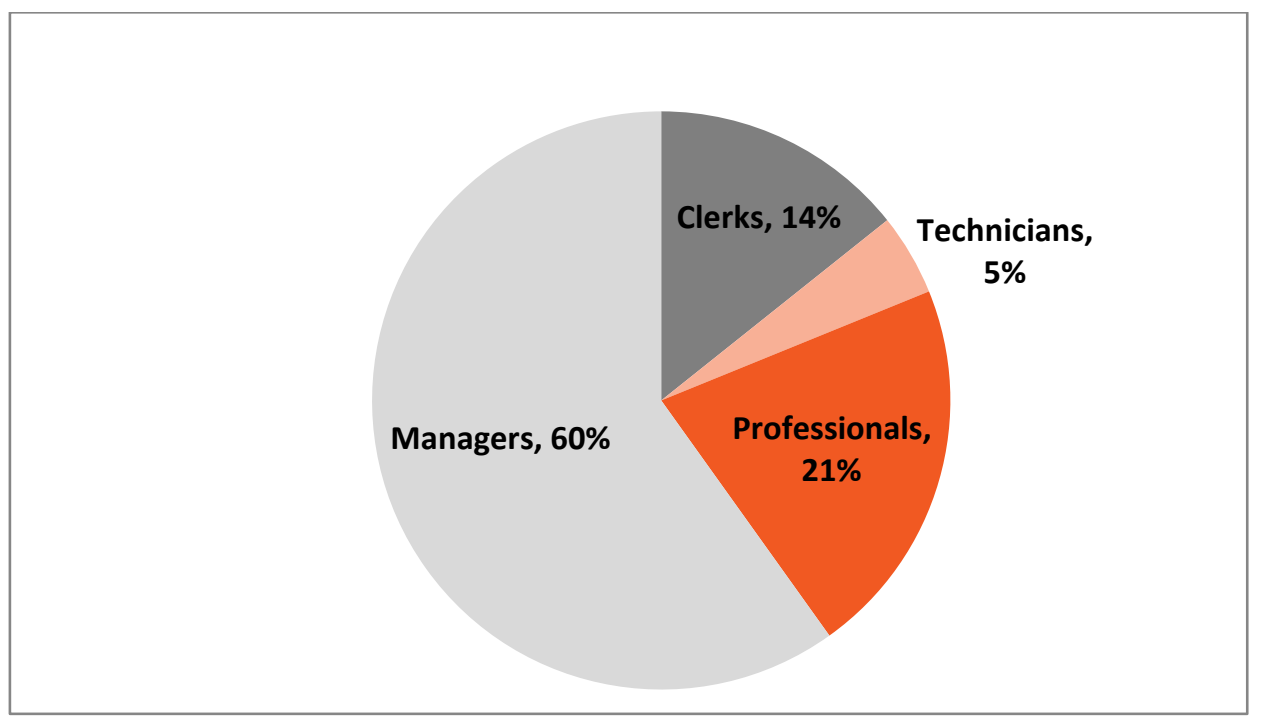

Figure 6. Percentage of female roles in textbooks according to their category 
Looking closely at the departments these women worked for, we have found that almost the same number worked for Sales (26), Human Resources (25), Finance and Accounts (25) and Marketing (23). On the other hand, 28 are entrepreneurs who set up their own business.

The qualitative evaluation of pictures throughout these textbooks revealed how women have changed their role in different business environments. In the 1980s, they were barely represented in pictures; those who did performed secretarial jobs or even housework such as shopping in supermarkets. In the 1990s, a change is observed, when women start to be depicted in business-related situations such as meetings and presentations; they become visible for the first time. This change is more marked in the 2000s and 2010s, with men and women portrayed alike.

Regarding actual successful businesswomen, it is not until the 1980s that they are featured in some textbooks. In the 1990s and 2010s several businesswomen are mentioned. However, the inclusion of successful actual business people tends to disappear from textbooks altogether in more recent years; now the focus is on how things are done and case studies are mainly about companies, business strategies rather than concrete business people.

\section{CONCLUSIONS}

Textbooks are a reflection of society as they show its evolution over the years, " $(\mathrm{t})$ hey reflect the prevailing views of the historical period in which they are written" (Clark, 2005: 259). Accordingly, Business English materials are a valuable educational source of information to learn about companies and their female workforce.

One of the most relevant findings in this research clearly confirms that the number of women working in business settings has risen significantly over the decades. In early textbooks, males occupied most of the professional roles while women were almost invisible, whereas nowadays we can say that female representation is definitely more balanced. This finding agrees with other recently published studies of Business English textbooks (Bataineh, 2017; Dzięcioł-Pędich, 2017; Goyal \& Rose, 2020).

Catalyst (2020) states that as of June 2020, more than two-thirds $(72.7 \%)$ of women aged 16-64 were employed - a dramatic increase in women's presence in the labour market compared to $52.8 \%$ in the first quarter (January-March) of 1971. Since the 1970s the situation of women at work has been changing and this fact is reflected in the textbooks used for this article. However, the results of the study disagree with the information provided by the World Employment and Social Outlook (2020), which states that in 2019 the female labour force participation rate stood well below that of men. Nowadays, women hold over $40 \%$ of jobs worldwide, though 
often with lower pay. They manage a third of all world businesses, however, these are essentially micro and small businesses (ILO, 2015).

The occupations performed by women have also evolved over the years covered in this study. In the oldest textbooks analyzed, women fulfilled clerical occupations mainly (secretary, switchboard operator, etc.) and this number has declined remarkably over the years. Surprisingly, the proportion of women occupying positions as technicians has not varied much; barely $4 \%$ of women counted in the research.

The most remarkable change in women's working patterns is an increase in professional and managerial jobs $(21 \%$ and $60 \%$ of the total female characters included in the 35 books of the study). The textbooks examined for the last decade show an increase of women in managerial positions, from $17 \%$ in the 1970 s to $71 \%$ in the last decade included in this study. Therefore, we can conclude that recent publications reflect female roles in business contexts in terms of growth and higherranked positions.

However, these data do not match the information recorded by official organizations. In 2016, only $5 \%$ of executive directors or managing directors in large companies in the EU were women (Rincón et al., 2017). According to Beghini, Cattaneo, and Pozzan (2019), currently only 27.1\% of managers and leaders are women, a figure that has changed very little over the past decades. Similar data is found in the 2020 edition of Sex and Power by The Fawcett Society, a UK charity campaigning for women's rights which reveals that women make up just over one in twenty Chief Executive Officers of Financial Times Stock Exchange 100 companies (6\%) (Kaur, 2020). Authors such as López-Fernández, Martín-Alcázar, and RomeroFernández (2009) point out that women's access to managerial posts in the real world is still hindered by several barriers. These barriers, such as challenges to promotion, sexual discrimination, sexist attitudes as well as changes in past and present female occupations appear in some of the textbooks reviewed for this study.

As for visual elements, images play a very relevant role in communication nowadays, whereas it was not so some years ago. The oldest textbooks examined had few pictures and even fewer of those included women, who were depicted in traditional roles. However, there has undoubtedly been a deep change in the presentation of women in textbooks as a consequence of social evolution. Over the years, women have been promoted to higher business positions, from operators using switchboards in the 1970s to managers giving presentations or leading meetings in the 2010s. Illustrations feature women working as an essential element in companies and performing different tasks. All these images evidence the transformation that has taken place over the past 50 years.

The introduction of actual businesswomen in the textbooks as case studies or reading comprehension exercises is quite limited. The strategy of inserting texts about successful businessmen started in the 1980s. Over the next two decades, it was common to read about well-known international businessmen; however, it was unusual to find readings about businesswomen. Surprisingly, just 11 actual 
businesswomen were mentioned in 6 textbooks - one published in 1984, two in 1993, one in 2008 as well as another two published in 2012 and 2017 respectively. It seems that this trend of introducing well-known business people as examples in textbooks has clearly declined.

Female roles in Business English textbooks in the last fifty years reflect the development of a more egalitarian society to a certain extent. Gender equality in the real world has not been achieved yet. Although there is a greater balance between men and women in positions with a medium level of responsibility, women are barely represented in senior management positions, despite showing the same level of expertise as men (Akpinar-Sposito, 2013; Rincón et al., 2017). Women often take the jobs that men do not want (Powell \& Butterfield, 2015) and participate in labour markets on an unequal basis with their male colleagues (Dzięcioł-Pędich, 2017). Even though diversity and improved business performance are inextricably linked, gender diversity in management positions is shifting at a painfully slow rate (Grant Thornton, 2017). In the last 50 years women have definitely improved their position in the business world but there is still a long way to go. Where figures are available, women's presence at senior management level is low - the "glass ceiling" is still in place. The textbooks examined in our study reflect reality just partially and may even give an overly optimistic view of it.

[Paper submitted 29 Apr 2021]

[Revised version received 5 Sep 2021]

[Revised version accepted for publication 11 Nov 2021]

\section{References}

Adel, S. M. R., \& Enayat, M. J. (2016). Gender representation and stereotyping in ESP textbooks. Asian ESP Journal, 12(3), 94-119.

Akpinar-Sposito, C. (2013). Career barriers for women executives and the glass ceiling syndrome: The case study comparison between French and Turkish women executives. Procedia - Social and Behavioral Sciences, 75, 488-497. https://doi.org/10.1016/j.sbspro.2013.04.053

Amerian, M., \& Esmaili, F. (2015). Language and gender: A critical discourse analysis on gender representation in a series of international ELT textbooks. International Journal of Research Studies in Education, 4(2), 3-12.

Amini, M., \& Birjandi, P. (2012). Gender bias in the Iranian high school EFL textbooks. English Language Teaching, 5(2), 134-147. Retrieved from https://files.eric.ed.gov/fulltext/EJ1078900.pdf

Ansary, H., \& Babaii, E. (2003). Subliminal sexism in current ESL/EFL textbooks. Asian EFL Journal, 5(1), 1-15.

Arikan, A. (2005). Age, gender and social class in ELT coursebooks: A critical study. Hacettepe Üniversitesi Eğitim Fakültesi Dergisi, 28, 29-39. Retrieved from https://files.eric.ed.gov/fulltext/ED494162.pdf

Bahman, M., \& Rahimi, A. (2010). Gender representation in EFL materials: An analysis of English textbooks of Iranian high schools. Procedia - Social and Behavioral Sciences, 9, 273-277. https://doi.org/10.1016/j.sbspro.2010.12.149 
Bargiela-Chiappini, F., \& Zhang, Z. (2013). Business English. In B. Paltridge, \& S. Starfield (Eds.), The handbook of English for specific purposes (pp. 193-212). Blackwell.

Bataineh, A. (2017). Analysis of gender representation in pre-intermediate Market leader: Business English practice file. International Journal of Humanities and Social Science, 7(2), 50-55. Retrieved from https://www.ijhssnet.com/journals/Vol_7_No_2_February_2017/7.pdf

Beghini, V., Cattaneo, U., \& Pozzan, E. (2019). A quantum leap for gender equality: For a better future of work for all. International Labour Organization.

Catalyst. (2020, July 9). Women in the workforce: UK (Quick take). Retrieved from https://www.catalyst.org/research/women-in-the-workforce-uk/

Clark, P. (2005). "A nice little wife to make things pleasant": Portrayals of women in Canadian history textbooks approved in British Columbia. McGill Journal of Education, 40(2), 241-265.

Domenico, D. M., \& Jones, K. (2007). Career aspirations of women in the 20th century. Journal of Career and Technical Education, 22(2), 1-7.

Dudley-Evans, T., \& St John, M. J. (1996). Report on business English: A review of research and published teaching materials (TOEIC Research report No. 2). Educational Testing Service.

Dzięciol-Pędich, A. (2017). The image of the corporate world in business English speaking exercises at upper intermediate level. Bialostockle Archiwum Jezykowe, 5, 141-161.

Filak, A. (2002). Men and women between cultures: Gender stereotypes in EFL coursebooks in Poland. Neolit Online: A Culture In-Between, 1(2), 1-49.

Frendo, E. (2005). How to teach business English. Pearson Education Limited.

Fuertes-Olivera, P. A. (2007). A corpus-based view of lexical gender in written business English. English for Specific Purposes, 26, 219-234.

Gharbavi, A., \& Mousavi, S. A. (2012). A content analysis of textbooks: Investigating gender bias as a social prominence in Iranian high school English textbooks. English Linguistics Research, 1(1), 42-49.

Giaschi, P. (2000). Gender positioning in education: A critical image analysis of ESL texts. TESL Canada Journal, 18(1), 32-46.

Goyal, R., \& Rose, H. (2020). Stilettoed damsels in distress: The (un)changing depictions of gender in a business English textbook. Linguistics and Education, 58. https://doi.org/10.1016/j.linged.2020.100820

Grant Thornton. (2017, March 8). Women in business 2017. Retrieved from https://www.grantthornton.global/en/insights/articles/women-in-business-2017/

Hamdan, S. (2010). English-language textbooks reflect gender bias: A case study in Jordan. Advances in Gender and Education, 2, 22-26.

Healy, D. (2009). The representation of women and men in a modern EFL textbook: Are popular textbooks gender biased? Memoirs of the Osaka Institute of Technology, 54(2), 91-100.

Holmqvist, P., \& Gjörup, L. (2007). The representation of gender and gender roles in English textbooks. Malmö Högskola.

International Labour Organization. (2015). Women in business and management: Gaining momentum. Retrieved from https://www.ilo.org/global/publications/ilobookstore/order-online/books/WCMS_316450/lang--en/index.htm

ISCO: International standard classification of occupations (ISCO-08). (2016, June 21). International Labour Organization. Retrieved from https://www.ilo.org/public/english/bureau/stat/isco/isco08/index.htm

Jalilvad, M. (2000). Married women, work and values. Monthly Labor Review, 2000, 26-31. 
Kankaanranta, A., \& Louhiala-Salminen, L. (2013). What language does global business speak? The concept and development of BELF. Ibérica, 26, 17-34.

Kaur, S. (2020). Sex \& power. The Fawcett Society.

Lario-de-Oñate, M. C. (2007). A review of business English textbooks (1963-2006). In A. Bocanegra Valle, M. C. Lario-de-Oñate, \& E. López Torres (Eds.), English for specific purposes: Studies for classroom development and implementation (pp. 11-31). Servicio Publicaciones Universidad de Cádiz.

Lario-de-Oñate, M. C., \& Vázquez-Amador, M. (2013). The intercultural component of business English textbooks. Ibérica, 26, 171-194.

Lee, J. F. K. (2014). Gender representation in Hong Kong primary school ELT textbooks: A comparative study. Gender and Education, 26(4), 356-376. https://doi.org/10.1080/09540253.2014.916400

Lee, J. F. K., \& Collins, P. (2009). Australian English-language textbooks: The gender issues. Gender and Education, 21(4), 353-370. https://doi.org/10.1080/09540250802392257

López-Fernández, M., Martín-Alcázar, F., \& Romero-Fernández, P. M. (2009). Key factors in the access of women to managerial posts. Journal of General Management, 34(4), 3950. https://doi.org/10.1177\%2F030630700903400403

Marefat, F., \& Marzban, S. (2014). Multimodal analysis of gender representation in ELT textbooks: Reader's perceptions. Procedia - Social and Behavioral Sciences, 98, 10931099. https://doi.org/10.1016/j.sbspro.2014.03.521

McGroarty, M. (2002). Language uses in professional contexts. In R. Kaplan (Ed.), The Oxford handbook of applied linguistics (pp. 262-276). Oxford University Press.

Molina-Plaza, M., \& Allani, S. (2020). Multimodal women engineers' identity construction. In A. Bocanegra-Valle (Ed.), Applied linguistics and knowledge transfer: Internationalisation, employability and social challenges (pp. 291-321). Peter Lang.

Nashriyah, N., \& Khairul, D. (2018). English senior high school textbook analysis: Addressing gender bias issues. Gender Equality: International Journal of Child and Gender Studies, $4(2), 1-14$.

Pillay, P. (2017). Gender representation in four SADC high school Business studies textbooks (Unpublished doctoral dissertation). University of KwaZulu-Natal, Durban, South Africa.

Powell, G. N., \& Butterfield, D. A. (2015). The preference to work for a man or a woman: A matter of sex or gender? Journal of Vocational Behavior, 86, 28-37.

Rincón, V., González, M., \& Barrero, K. (2017). Women and leadership: Gender barriers to senior management positions. Intangible Capital, 13(2), 319-386. http://dx.doi.org/10.3926/ic.889

Roohani, A., \& Zarei, M. (2013). Evaluating gender-bias in the Iranian pre-university English textbooks. Indonesian Journal of Applied Linguistics, 3(1), 115-125. https://doi.org/10.17509/ijal.v3i1.194

Scott J. L, Dex, S., \& Joshi, H. (2008). Women and employment: Changing lives and new challenges. Edward Elgar Publishing Limited.

St John, M. J. (1996). Business is booming: Business English in the 1990s. English for Specific Purposes, 15(1), 3-18. https://doi.org/10.1016/0889-4906(95)00023-2

Walsh, M., \& Wrigley, C. (2001). Womanpower: The transformation of the labour force in the UK and the USA since 1945. Recent Findings of Research in Economic and Social History, 30, 1-4.

World employment and social outlook. Trends 2020. (2020). International Labour Organization. Retrieved from https://www.ilo.org/global/research/globalreports/weso/2020/lang--en/index.htm 
Zagan-Zelter, D., \& Zagan-Zelter, S. (2010). Teaching business English: A challenge both for students and academics. Procedia - Social and Behavioral Sciences, 3, 245-250. https://doi.org/10.1016/j.sbspro.2010.07.039

Ziad, K., \& Ouahmiche, G. (2019). Gender positioning in the visual discourse of Algerian secondary education EFL textbooks: Critical image analysis vs teachers' perceptions. Journal of Language and Linguistic Studies, 15(3), 773-793.

\section{Textbooks}

Allison, J., \& Emmerson, P. (2013). Business 2.0. MacMillan Education.

Barber, W. (1974). Business world. Thomas Nelson and Sons Ltd.

Benn, C., \& Dummet, P. (1992). Business first. Heinemann.

Birkin, J. (2012). Business advantages. Oxford University Press.

Carrier, M. (1988). Business circles. Nelson.

Cotton, D. (1984). World of business. Bell \& Hyman Limited.

Cotton, D. (1988). Keys to management. Bell \& Hyman Limited.

Cotton, D., \& Robins, S. (1993). Business class. Nelson.

Cotton, D., Falvey, D., \& Kent, S. (2001). Market leader: Intermediate business English. Pearson Education Limited.

Danks, S., \& Cross, L. (1989). Assigments in business studies. Nelson.

Dubicka, I., Dignen, B., Hogan, M., \& Wright, L. (2018). Business partner. Pearson Education Limited.

Eckersley, C. E., \& Kaufman, W. (1973). A commercial course for foreign students. Longman.

Grant, D., \& McLarty, R. (1995). Business basics. Oxford University Press.

Hacikyan, A. J., \& Gill, M. (1980). Business in English. Regents Publishing Company.

Hellwell, M. (2014). Business plus. Cambridge University Press.

Hobbs, M., \& Keddle, J. S. (2006). Commerce. Oxford University Press.

Hollet, V. (1991). Business objectives. Oxford University Press.

Hollet, V., Carter, R., Lyon, L., \& Tanner, E. (1989). In at the deep end. Oxford University Press. Hughes, J., \& Nauton, J. (2017). Business results. Oxford University Press.

Ibbotson, M., \& Stephens, B. (2006). Start up 1. Cambridge University Press.

Jones, L., \& Alexander, R. (1996). New international business English. Cambridge University Press.

Jones-Macziola, S., \& White, G. (1993). Getting ahead. Cambridge University Press.

Lannon, M., Tullis, G., \& Trappe, T. (1993). Insights into business. Nelson.

Mack, A. (1972). The language of business. Ed. Alhambra.

MacKenzie, I. (2002). English for business studies. Cambridge University Press.

Maier-Fairclough, J., \& Butzphal, G. (2013). Career express. Garnet Education.

Mohr, B. (1978). The language of international trade in English. Regents Publishing.

Mol, H., \& Collie, J. (2012). Business update 1. Garnet Publishing.

Naunton, J. (2000). Head for business. Oxford University Press.

Norman, S. (1982). We mean business. Longman.

Powell, M. (2009). In company. MacMillan Education.

Scullion, M. (1987). Managing people. Hodder and Stoughton.

Sweeney, S. (1997). English for business communication. Cambridge University Press.

Wallwork, A. (2002). Business vision. Oxford University Press.

Watson-Delestrée, A., \& Hill, J. (1998). The working week. LTP Business. 
MARÍA VÁZQUEZ-AMADOR, PhD, is an assistant lecturer at the University of Cádiz in the French and English Department. She is a member of the research group "Lenguas Aplicadas a la comunicación académica y profesional" (LaCAP) and has recently collaborated in the Erasmus Project TRAILS_LSP Teacher Training Summer School. Her publications have appeared in national and international journals (Ibérica, Onomazein, Estudios filológicos, Tonos digital: Revista de estudios filológicos, Verbum). Her research focuses on the influence of English on Spanish, ESP methodology as well as business, tourism and nursing terminology.

M. CARMEN LARIO-DE-OÑATE, PhD, has been teaching English for Business for over thirty years at the University of Cádiz in the French and English Department. Her main research interests lie within the fields of cultural studies and discourse analysis. She has collaborated in the national project "Identidad e imagen de Andalucía en la Edad Moderna" and the international project "Grupos de poder, comunidades e individuos del norte de Europa en la Monarquía hispánica durante la Edad Moderna: Integración y diversidad". She has published in different journals (Ibérica, Cuadernos de Investigación de Fondos del Archivo UCA, Tonos digital, Verbum) and has collaborated in books related to her research profile. 